\title{
Cancer incidence and mortality among Swedish leather tanners
}

\author{
Zoli Mikoczy, Andrejs Schütz, Lars Hagmar
}

\begin{abstract}
Objectives-The aim was to study the incidence of cancer among Swedish leather tanners.

Methods-A cohort of 2026 subjects who had been employed for at least one year between 1900 and 1989 in three Swedish leather tanneries, was established. The cancer incidence and mortality patterns were assessed for the periods $1958-89$ and 1952-89 respectively, and cause-specific standardised incidence and mortality ratios (SIRs and SMRs) were calculated.

Results-A significantly increased incidence of soft tissue sarcomas (SIR 4.27, 95\% confidence interval ( $95 \%$ CI) 1.39-9.97) was found, based on five cases. Excesses, (not statistically significant) was also found for multiple myelomas (SIR 2.54, 95\% CI 0.93-5.53), and sinonasal cancer (SIR 3.77, 95\% CI 0.46-13.6).

Conclusions-The increased incidence of soft tissue sarcomas adds support to previous findings of an excess mortality in this diagnosis among leather tanners. A plausible cause is exposure to chlorophenols, which had occurred in all three plants. The excess of multiple myelomas may also be associated with exposure to chlorophenol. The association between incidence of cancer and specific chemical exposure will be elucidated in a cohortbased case-referent study.
\end{abstract}

(Occup Environ Med 1994;51:530-535)

Keywords: leather tanners; multiple myeloma; soft tissue sarcoma.

Many chemicals are handled in leather tanning and processing. Some of them are carcinogens or suspected carcinogens-for example, hexavalent chromium salts, vegetable tannins, chlorophenols, aniline dyes, formaldehyde, methylmercury, arsenic, benzene, and chlorinated organic solvents. ${ }^{1}$

It is well established that exposure to leather dust, especially in the shoe and boot industry, has caused increased risks for nasal cancer, ${ }^{2}$ but it is not clear whether tanning and leather processing also increase such a risk. Some results, although far from conclusive, indicate a possible association. ${ }^{34}$

An association between tanning and lung cancer has been reported, ${ }^{5-7}$ but was not found in other studies. ${ }^{389}$ Slight and non- significant increased risks for bladder cancer were found among workers in tanning and leather processing plants, ${ }^{1011}$ but not in all studies..$^{1213}$ An excess of mortality in soft tissue sarcomas among leather tanners has been indicated in two previous cohort studies, ${ }^{314}$ but this was based only on one and two incident cases. In previous Swedish studies an increased risk for pancreatic cancer ${ }^{8}$ and renal cancer, ${ }^{15}$ was found, and a cluster of testicula: cancer among workers in leather finishing departments has been reported. ${ }^{1617}$

Due to the inconsistent epidemiological results, the International Agency for Research on Cancer has not yet found it possible to conclude whether leather tanning and pro. cessing is associated with any excess risk or cancer. ${ }^{18}$ A likely explanation for the varying results of the epidemiological studies is that the chemical exposures have differed between the plants. It must therefore be of importance to elucidate whether specific chemical exposures in the tanning and finishing processes may be associated with risk of cancer.

The aim of the present study was to investigate the cancer incidence in a cohort of workers from three Swedish leather tanneries. The cohort can also serve as a study base for a case-referent study that will allow a more detailed analysis with respect to associations between specific chemical exposures and specific tumours.

Materials and methods PRODUCTION AND EXPOSURE

Plant A was run between 1906 and 1988, manufacturing coloured nappa (full grain) leather, mainly for shoes (uppers). Chromium compounds dominated in the tanning processes, but a minor department at the factory produced leather tanned by vegetable dyes for book binding until the late 1960s. Arsenic sulphides were used in the liming and hair removing procedure until about 1950 . Up to about 1960 , mercury compounds may have been used for the preservation of the stored raw hides; later only sodium chloride was used. During the $1940 \mathrm{~s}$, methylmercury was added to the soaking and tanning baths to prevent the development of mould in damp leather stored at the factory, and in semimanufactured products (bovine hide split) for export. From about 1950, methylmercury was replaced by chlorophenols, which were in use until 1980. Azo dyes were widely used for deep colouring of leather during the entire production period. Black dyes, based on 
benzidine, were used until 1980. Pigments containing azo dyes were also used for surface colouring at the finishing department. Formaldehyde solutions $(5-10 \% \mathrm{v} / \mathrm{v})$ were extensively used for curing water soluble casein based surface coatings. These coatings were gradually replaced by organic solvent based nitrocellulose coatings, which were introduced in the late 1920s. Formaldehyde curing casein coatings were practically out of use after the mid 1970s. The use of organic solvents in the finishing department was at a maximum during the $1970 \mathrm{~s}$. The coatings based on organic solvents were partly replaced by water dispersed nitrocellulose, acrylate, or uretane polymers. During the last years, the proportions between solvent and water based coatings were about equal. The organic solvents used were mainly butyl acetate, cyclohexanone, ethanol, ethyl acetate, ethylene glycol, methylethyl ketone, methylisobutyl ketone, toluene, and xylene. Benzene was a frequent contaminant of technical toluene up to the mid-1960s.

Plant B was run between 1897 and 1989, manufacturing nappa and suede leather for gloves and garments. For tanning, vegetable tannins, formaldehyde, aluminium, and chromium compounds were used. Formaldehyde tanning involved extensive exposure to formaldehyde, but was done on a limited scale and practically disappeared after 1965. Chromium tanning was introduced in about 1930. Arsenic compounds were probably used as preservatives of the imported, raw skins. Arsenic sulphides were used in the liming procedure until the early 1950s. Methylmercury compounds were used as preservatives probably from the early 1940 s until the beginning of the $1960 \mathrm{~s}$. They were replaced by chlorophenols, which were used until 1980 and then again in the second half of the $1980 \mathrm{~s}$. About $50 \%$ of the skins were degreased through extraction with organic solvents. The earliest degreasing agent was petrol, which probably contained benzene. It was replaced by trichloroethylene (during the 1950s and 1960s) and 1,1,1-trichloroethane (during the 1970s and 1980s). During the 1980s perchloroethylene was occasionally used. The degreasing operation involved considerable solvent exposure for some process operators. Judged from the earliest available data on the excretion of trichloroacetic acid in urine, these workers were exposed to daily average air concentrations of trichloroethylene in the range of $50-200 \mathrm{ppm}$ in 1964 . From the beginning of the $1980 \mathrm{~s}$, the exposure to degreasing agents was considerably reduced

Table 1 Vital status as of 31 December 1989 among workers employed for at least one year in three Swedish leather tanneries

\begin{tabular}{lccclc}
\hline Tannery & Living in Sweden & Dead & Emigrated & Lost to follow up & Total \\
\hline A & 418 & 52 & 7 & 0 & 477 \\
B & 681 & 233 & 9 & 3 & 927 \\
C & 427 & 189 & 8 & 2 & 627 \\
All & 1526 & 474 & 24 & 5 & 2031 \\
\hline
\end{tabular}

through technical measures. Most of the skins were deeply coloured with azo and benzidine dyes. Formaldehyde curing caseine coatings were in use until 1975 . In the early 1950 s, water dispersed polymer coatings were introduced and totally replaced the solvent based coatings from the late 1960 s.

Plant $\mathrm{C}$ was run in the same premises from 1860 until it closed down in 1991. Until 1960 , the dominating product was sole leather treated with vegetable tannins. These were extracts from quebracho (South America), mimosa (South Africa), chestnut (Italy), and domestic oak and pine. Extracts from the mangrove tree were used for dyeing. A small production of leather tanned with chrome alum started in the 1940 s. During the first half of the $1960 \mathrm{~s}$, the main production changed from sole leather to chrome tanned, coloured nappa for shoes (uppers), suitcases, and leather gifts. Methylmercury was used as a fungicide in the tanning process until about the mid-1950s. It was replaced by chlorophenols, which were in use until 1979. Dyes derived from azo compounds and benzidine were extensively used for the chrome tanned, soft leather. The use of such dyes increased during the last years due to customer demand for leather coloured throughout. The large increase in the production of soft leather led, from the beginning of the $1960 \mathrm{~s}$, to a corresponding increase in the use of surface coatings, and thus to an increased consumption of organic solvents. The products used were similar to those used in plant $A$, although a larger proportion of the coatings were water based.

\section{COHORT}

Name, date of birth, address, and dates of start and end of employment were obtained for the blue collar workers through each of the three company records. For plant A, the company record comprised subjects employed from 1917 onwards, but was not considered as complete and valid until 1966. The corresponding calendar-years for plant B were 1900 and 1930, and for plant C 1902 and 1946.

For 92 workers the Swedish 10 digit personal identification code could not be retrieved, and they were thus excluded from the cohort. Another 51 subjects were excluded as they had died or emigrated before the start of the observation periods, and 10 subjects were excluded because they were 80 or older at the start of the observation periods. The remaining 3613 workers had been employed for at least one day before 1987 . Of those, 2031 who had been employed for at least one year before 1987,482 were women and 1549 were men. Vital status was determined on December 311989 (table 1). Only five subjects $(0.2 \%)$ were lost to follow up. The final cohort thus comprised 2026 subjects, providing 42548 person-years under risk. The average duration of employment in the cohort was 12.7 years, the average first year of exposure was 1955, and the average duration of follow up was $21 \cdot 7$ years. 
Table 2 Mortality 1952-89 in 2060 subjects employed for at least one year, by time since first exposure

\begin{tabular}{|c|c|c|c|c|c|c|c|c|c|c|c|c|c|}
\hline \multirow[b]{3}{*}{ Cause of death } & \multirow[b]{3}{*}{$I C D-8$} & \multicolumn{12}{|c|}{ Years since first exposure } \\
\hline & & \multicolumn{4}{|l|}{$1-10$} & \multicolumn{4}{|l|}{$>10$} & \multicolumn{4}{|c|}{ Total } \\
\hline & & 0 & $E$ & $S M R$ & $(95 \% C I)$ & 0 & $E$ & $S M R$ & $(95 \% C I)$ & $O$ & $E$ & $S M R$ & $(95 \% C I)$ \\
\hline \multirow{6}{*}{$\begin{array}{l}\text { Malignant } \\
\text { tumours } \\
\text { Cardiovascular } \\
\text { diseases } \\
\text { Ischemic heart } \\
\text { diseases } \\
\text { Respiratory } \\
\text { diseases } \\
\text { Asthma, bronchitis, } \\
\text { emphysema } \\
\text { Accidents, poisonings, } \\
\text { and violence } \\
\text { All causes }\end{array}$} & $140-209$ & 53 & $48 \cdot 4$ & $1 \cdot 10$ & $(0 \cdot 83-1 \cdot 44)$ & 66 & $60 \cdot 6$ & 1.09 & $(0.85-1.39)$ & 119 & 109 & 1.09 & $(0.91-1.31)$ \\
\hline & $390-458$ & 77 & $75 \cdot 4$ & 1.02 & $(0 \cdot 81-1 \cdot 28)$ & 117 & 119 & 0.99 & $(0 \cdot 82-1 \cdot 18)$ & 194 & 194 & 1.00 & $(0 \cdot 87-1 \cdot 15)$ \\
\hline & $410-414$ & 44 & $51 \cdot 3$ & 0.86 & $(0 \cdot 63-1 \cdot 16)$ & 84 & $81 \cdot 1$ & 1.03 & $(0.83-1 \cdot 29)$ & 128 & 132 & 0.97 & $(0 \cdot 81-1 \cdot 15)$ \\
\hline & $460-519$ & 6 & 8.5 & $0 \cdot 71$ & $(0 \cdot 26-1 \cdot 54)$ & 12 & $13 \cdot 1$ & 0.92 & $(0 \cdot 47-1.60)$ & 18 & $21 \cdot 6$ & 0.83 & $(0.50-1 \cdot 34)$ \\
\hline & $490-493$ & 4 & $3 \cdot 4$ & $1 \cdot 18$ & $(0 \cdot 32-3 \cdot 03)$ & 2 & $4 \cdot 8$ & 0.42 & $(0.05-1.50)$ & 6 & $8 \cdot 2$ & 0.73 & b.27-1.59) \\
\hline & $\begin{array}{r}800-999 \\
000-999\end{array}$ & $\begin{array}{r}29 \\
183\end{array}$ & $\underset{172}{21 \cdot 7}$ & $\begin{array}{l}1.34 \\
1.06\end{array}$ & $\begin{array}{l}(0.91-1.94) \\
(0.92-1.23)\end{array}$ & $\begin{array}{r}18 \\
237\end{array}$ & 234 & $\begin{array}{l}1.03 \\
1.01\end{array}$ & $\begin{array}{l}(0.62-1.65) \\
(0.89-1.15)\end{array}$ & $\begin{array}{r}47 \\
420\end{array}$ & $\begin{array}{l}39 \cdot 2 \\
406\end{array}$ & $\begin{array}{l}1.20 \\
1.04\end{array}$ & $\begin{array}{l}(0.89-1.60) \\
(0.94-1.14)\end{array}$ \\
\hline
\end{tabular}

$\mathrm{O}=$ Observed number of deaths; $\mathrm{E}=$ expected number of deaths; SMR = standardised mortality ratio.

INFORMATION ON CAUSES OF DEATH AND TUMOURS

Information on cause of death (1952-89) was obtained from Statistics Sweden. The death certificates were coded according to the International Classification of Diseases (ICD). These codes were transformed to the 8th revision of the ICD (ICD-8). Information on tumours (coded according to the ICD, 7th revision (ICD-7)) diagnosed from 1958 to 1989, was obtained from the National Swedish Tumour Registry.

\section{RISK ESTIMATES}

Expected mortality for the period 1952-89 was calculated from calendar-year, cause, sex, and five year age group specific mortalities for each of the two counties where the plants had been located. These were obtained from Statistics Sweden. Date of death, emigration, or a persons 80 th birthday were used as individual end points, whichever occurred first. Similarly, yearly incidence rates for cancer in the period 1958-89 were obtained from the National Swedish Tumour Registry, from calendar-year, sex, and five year age group specific incidence rates for each of the two counties. Date of death, tumour diagnosis, emigration, or a persons 80th birthday were used as individual end points, whichever occurred first. Cause specific standardised mortality/incidence ratios (SMRs/SIRs) and $95 \%$ confidence intervals ( $95 \% \mathrm{CIs}$ ) were calculated according to the Poisson distribution, or to the $\chi^{2}$ distribution if the expected values were greater than 10 .

Table 3 Cancer incidence 1958-1989 in 2026 subjects employed for at least one year and in 1417 subjects when a 20 year induction-latency period was used

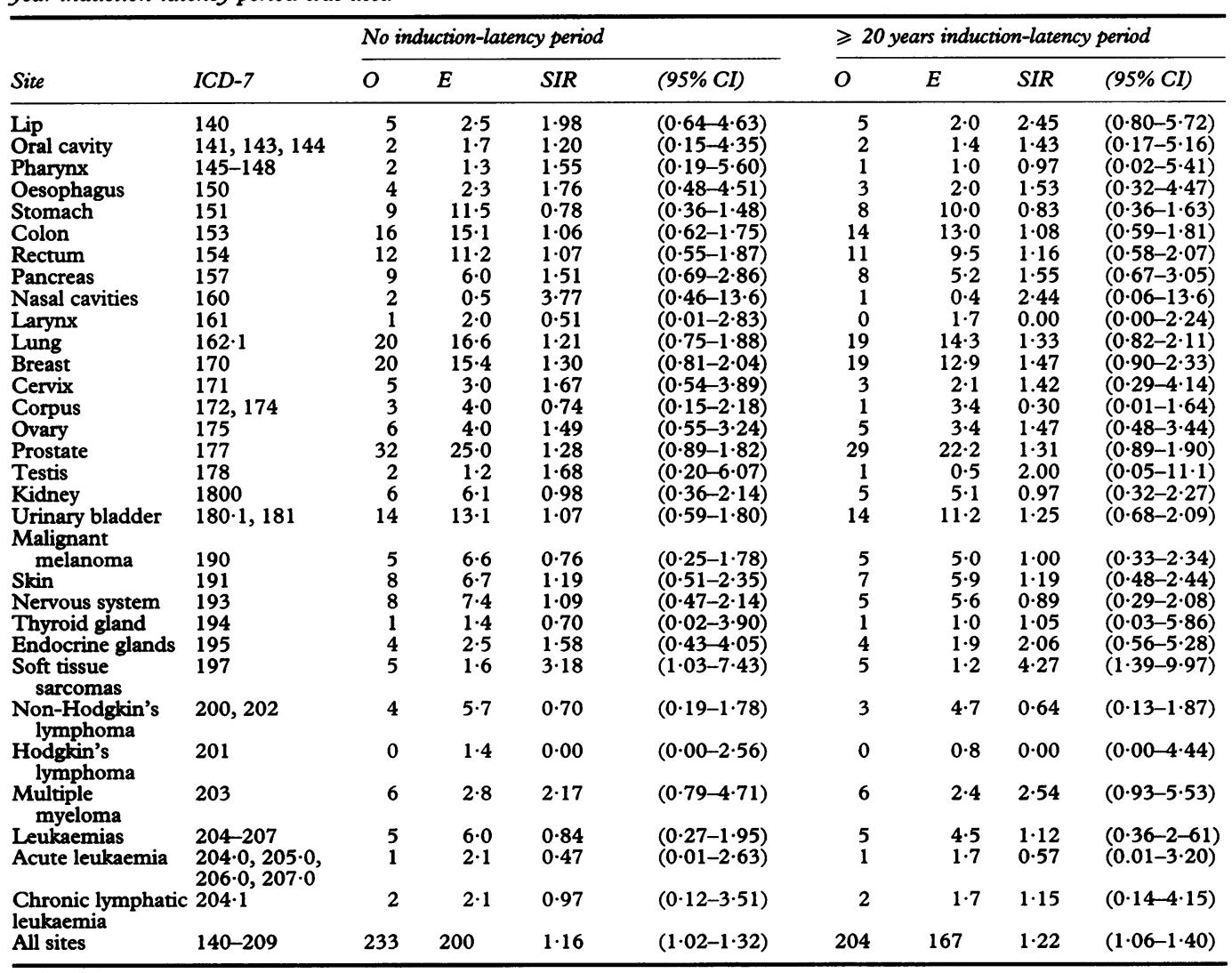

$\mathrm{O}=$ Observed number of cases; $\mathrm{E}=$ expected number of cases; SIR = standardised incidence ration. 
Table 4 Cancer incidence 1958-89 in 1417 subjects employed for at least one year, with a 20 year minimum induction latency period

\begin{tabular}{|c|c|c|c|c|c|c|c|c|c|c|c|c|c|}
\hline \multirow[b]{2}{*}{ Tumour site } & \multirow[b]{2}{*}{$I C D-7$} & \multicolumn{4}{|c|}{ Plant $A$} & \multicolumn{4}{|c|}{ Plant B } & \multicolumn{4}{|c|}{ Plant C } \\
\hline & & $O$ & $E$ & SIR & $(95 \% C I)$ & $O$ & $E$ & SIR & $(95 \% C I)$ & $O$ & $E$ & SIR & $(95 \% C I)$ \\
\hline $\begin{array}{l}\text { Lip } \\
\text { Stomach } \\
\text { Pancreas } \\
\text { Lung } \\
\text { Breast } \\
\text { Prostate } \\
\text { Kidney }\end{array}$ & $\begin{array}{l}140 \\
151 \\
157 \\
162 \cdot 1 \\
170 \\
177 \\
180 \cdot 0\end{array}$ & $\begin{array}{l}0 \\
0 \\
1 \\
1 \\
0 \\
2 \\
0\end{array}$ & $\begin{array}{l}0.2 \\
0.9 \\
0.6 \\
1.3 \\
0.4 \\
2.7 \\
0.5\end{array}$ & $\begin{array}{l}0.00 \\
0.00 \\
1.61 \\
0.75 \\
0.00 \\
0.75 \\
0.00\end{array}$ & $\begin{array}{l}(0.00-17 \cdot 1) \\
(0.00-4.09) \\
(0.04-8.95) \\
(0.02-4.17) \\
(0.00-10.6) \\
(0.09-2 \cdot 70) \\
(0.00-7.05)\end{array}$ & $\begin{array}{r}2 \\
6 \\
5 \\
14 \\
18 \\
13 \\
3\end{array}$ & $\begin{array}{r}1 \cdot 0 \\
5 \cdot 5 \\
3 \cdot 7 \\
9 \cdot 0 \\
12 \cdot 4 \\
11 \cdot 3 \\
3 \cdot 1\end{array}$ & $\begin{array}{l}1.94 \\
1.09 \\
1.36 \\
1.55 \\
1.45 \\
1.15 \\
0.96\end{array}$ & $\begin{array}{l}(0 \cdot 24-7 \cdot 02) \\
(0 \cdot 40-2 \cdot 37) \\
(0 \cdot 44-3 \cdot 18) \\
(0 \cdot 85-2 \cdot 61) \\
(0 \cdot 88-2 \cdot 33) \\
(0 \cdot 61-1 \cdot 96) \\
(0 \cdot 20-2 \cdot 81)\end{array}$ & $\begin{array}{r}3 \\
2 \\
3 \\
4 \\
1 \\
14 \\
2\end{array}$ & $\begin{array}{l}0 \cdot 8 \\
3 \cdot 3 \\
1 \cdot 7 \\
3.9 \\
0 \cdot 2 \\
8 \cdot 2 \\
1.5\end{array}$ & $\begin{array}{l}3.81 \\
0.61 \\
1.77 \\
1.02 \\
6.06 \\
1.71 \\
1.33\end{array}$ & $\begin{array}{l}(0.79-11 \cdot 1) \\
(0.07-2 \cdot 21) \\
(0.37-5 \cdot 18) \\
(0 \cdot 28-2 \cdot 62) \\
(0.15-33.8) \\
(0.94-2 \cdot 87) \\
(0.16-4.81)\end{array}$ \\
\hline $\begin{array}{l}\text { sarcoma } \\
\text { Myeloma }\end{array}$ & $\begin{array}{l}197 \\
203\end{array}$ & $\begin{array}{l}0 \\
1\end{array}$ & $\begin{array}{l}0.1 \\
0.3\end{array}$ & $\begin{array}{l}0.00 \\
3.88\end{array}$ & $\begin{array}{l}(0 \cdot 00-33 \cdot 3) \\
(0 \cdot 10-21 \cdot 6)\end{array}$ & $\begin{array}{l}2 \\
3\end{array}$ & $\begin{array}{l}0 \cdot 8 \\
1 \cdot 3\end{array}$ & $\begin{array}{l}2 \cdot 60 \\
2 \cdot 25\end{array}$ & $\begin{array}{l}(0.32-9.40) \\
(0.46-6.56)\end{array}$ & $\begin{array}{l}3 \\
2\end{array}$ & $\begin{array}{l}0.3 \\
0.8\end{array}$ & $\begin{array}{c}10 \cdot 5 \\
2.63\end{array}$ & $\begin{array}{l}(2 \cdot 16-30 \cdot 6) \\
(0 \cdot 32-9 \cdot 51)\end{array}$ \\
\hline All & $140-209$ & 17 & 14.6 & $1 \cdot 16$ & $(0 \cdot 69-1 \cdot 89)$ & 127 & 110 & $1 \cdot 15$ & $(0.96-1 \cdot 38)$ & 60 & $42 \cdot 8$ & $1 \cdot 40$ & $(1 \cdot 08-1 \cdot 81)$ \\
\hline
\end{tabular}

$\mathrm{O}=$ Observed number of cases; $\mathrm{E}=$ expected number of cases; SIR = standardised incidence ratio.

Table 5 Standardised incidence ratios (SIRs) for some tumours with respect to of duration of employment and calender year for start of employment: the first 20 years since start of employment were exluded from the observation period

\begin{tabular}{|c|c|c|c|c|c|c|c|c|c|c|c|c|c|}
\hline \multirow[b]{3}{*}{ Tumour } & \multirow{3}{*}{$\begin{array}{l}\text { Start of } \\
\text { employment } \\
\text { (calendar-year) }\end{array}$} & \multicolumn{12}{|c|}{ Duration of employment } \\
\hline & & \multicolumn{4}{|c|}{$1-10$} & \multicolumn{4}{|c|}{$>10$} & \multicolumn{4}{|c|}{ Total } \\
\hline & & $O$ & $E$ & SIR & $(95 \% C I)$ & $O$ & $E$ & SIR & $(95 \% C I)$ & $O$ & $E$ & $S I R$ & $(95 \% C I)$ \\
\hline \multicolumn{14}{|l|}{ Lung cancer: } \\
\hline & $\begin{array}{l}<1950 \\
\geqslant 1950 \\
\text { All }\end{array}$ & $\begin{array}{l}6 \\
1 \\
7\end{array}$ & $\begin{array}{l}4 \cdot 3 \\
1 \cdot 1 \\
5 \cdot 4\end{array}$ & $\begin{array}{l}1.38 \\
0.90 \\
1.29\end{array}$ & $\begin{array}{l}(0.51-3.02) \\
(0.02-5.02) \\
(0.52-2.65)\end{array}$ & $\begin{array}{r}11 \\
1 \\
12\end{array}$ & $\begin{array}{l}8 \cdot 1 \\
0.7 \\
8 \cdot 9\end{array}$ & $\begin{array}{l}1.35 \\
1.35 \\
1.35\end{array}$ & $\begin{array}{l}(0.67-2.42) \\
(0.03-7.53) \\
(0.70-2.36)\end{array}$ & $\begin{array}{r}17 \\
2 \\
19\end{array}$ & $\begin{array}{l}12 \\
1.9 \\
14\end{array}$ & $\begin{array}{l}1.36 \\
1.08 \\
1.33\end{array}$ & $\begin{array}{l}(0 \cdot 81-2 \cdot 22) \\
(0.13-3 \cdot 91) \\
(0.82-2 \cdot 10)\end{array}$ \\
\hline \multicolumn{14}{|c|}{ Prostate cancer: } \\
\hline Soft tiscue sarco & $\begin{array}{l}<1950 \\
\geqslant 1950 \\
\text { All }\end{array}$ & $\begin{array}{l}3 \\
3 \\
6\end{array}$ & $\begin{array}{l}5 \cdot 2 \\
1 \cdot 6 \\
6 \cdot 8\end{array}$ & $\begin{array}{l}0.58 \\
1.91 \\
0.89\end{array}$ & $\begin{array}{l}(0.12-1.69) \\
(0.39-5.58) \\
(0.33-1.93)\end{array}$ & $\begin{array}{r}21 \\
2 \\
23\end{array}$ & $\begin{array}{c}14 \\
1 \cdot 2 \\
15 \cdot 4\end{array}$ & $\begin{array}{l}1.47 \\
1.72 \\
1.49\end{array}$ & $\begin{array}{l}(0.93-2.84) \\
(0.21-6.23) \\
(0.96-2.27)\end{array}$ & $\begin{array}{r}24 \\
5 \\
29\end{array}$ & $\begin{array}{c}19 \\
2 \cdot 7 \\
22 \cdot 2\end{array}$ & $\begin{array}{l}1.23 \\
1.83 \\
1.31\end{array}$ & $\begin{array}{l}(0.80-1.86) \\
(0 \cdot 59-.4 \cdot 27) \\
(0.88-1.90)\end{array}$ \\
\hline Soft tissue sarcc & $\begin{array}{l}\text { Comas: } \\
<1950 \\
\geqslant 1950 \\
\text { All }\end{array}$ & $\begin{array}{l}1 \\
1 \\
2\end{array}$ & $\begin{array}{l}0.4 \\
0.1 \\
0.5\end{array}$ & $\begin{array}{l}2 \cdot 33 \\
10 \cdot 0 \\
3 \cdot 77\end{array}$ & $\begin{array}{l}(0.06-13 \cdot 0) \\
(0.25-55 \cdot 7) \\
(0.46-13 \cdot 6)\end{array}$ & $\begin{array}{l}3 \\
0 \\
3\end{array}$ & $\begin{array}{l}0.6 \\
0.1 \\
0.6\end{array}$ & $\begin{array}{l}5 \cdot 26 \\
0 \cdot 00 \\
4 \cdot 69\end{array}$ & $\begin{array}{l}(1 \cdot 09-15 \cdot 4) \\
(0 \cdot 00-52 \cdot 7) \\
(0.97-13 \cdot 7)\end{array}$ & $\begin{array}{l}4 \\
1 \\
5\end{array}$ & $\begin{array}{l}1 \cdot 0 \\
0 \cdot 2 \\
1 \cdot 2\end{array}$ & $\begin{array}{l}4 \cdot 00 \\
5 \cdot 88 \\
4 \cdot 27\end{array}$ & $\begin{array}{l}(1 \cdot 09-10 \cdot 2) \\
(0 \cdot 15-32 \cdot 8) \\
(1 \cdot 39-10 \cdot 0)\end{array}$ \\
\hline Myelomas: & $\begin{array}{l}<1950 \\
\geqslant 1950 \\
\text { All }\end{array}$ & $\begin{array}{l}3 \\
0 \\
3\end{array}$ & $\begin{array}{l}0.8 \\
0 \cdot 2 \\
0.9\end{array}$ & $\begin{array}{l}3.90 \\
0 \cdot 00 \\
3 \cdot 19\end{array}$ & $\begin{array}{l}(0.80-11.4) \\
(0.00-21.7) \\
(0.66-9.33)\end{array}$ & $\begin{array}{l}3 \\
0 \\
3\end{array}$ & $\begin{array}{l}1 \cdot 3 \\
0 \cdot 1 \\
1 \cdot 4\end{array}$ & $\begin{array}{l}2 \cdot 29 \\
0 \cdot 00 \\
2 \cdot 11\end{array}$ & $\begin{array}{l}(0.47-6.69) \\
(0.00-33.5) \\
(0.44-6.17)\end{array}$ & $\begin{array}{l}6 \\
0 \\
6\end{array}$ & $\begin{array}{l}2 \cdot 1 \\
0 \cdot 3 \\
2 \cdot 4\end{array}$ & $\begin{array}{l}2 \cdot 88 \\
0.00 \\
2 \cdot 54\end{array}$ & $\begin{array}{l}(1.06-6.28) \\
(0.00-13.2) \\
(0.93-5.53)\end{array}$ \\
\hline All malignant to & $\begin{array}{l}\text { cumours: } \\
<1950 \\
\geqslant 1950 \\
\text { All }\end{array}$ & $\begin{array}{l}62 \\
15 \\
77\end{array}$ & $\begin{array}{l}58 \\
13 \\
70\end{array}$ & $\begin{array}{l}1.07 \\
1 \cdot 19 \\
1.09\end{array}$ & $\begin{array}{l}(0.82-1.37) \\
(0.67-1.96) \\
(0.86-1.37)\end{array}$ & $\begin{array}{r}117 \\
10 \\
127\end{array}$ & $\begin{array}{l}88 \\
8 \cdot 6 \\
97\end{array}$ & $\begin{array}{l}1.33 \\
1 \cdot 16 \\
1 \cdot 31\end{array}$ & $\begin{array}{l}(1 \cdot 10-1 \cdot 60) \\
(0 \cdot 56-2 \cdot 13) \\
(1 \cdot 10-1 \cdot 57)\end{array}$ & $\begin{array}{r}179 \\
25 \\
204\end{array}$ & $\begin{array}{r}146 \\
21 \\
167\end{array}$ & $\begin{array}{l}1 \cdot 22 \\
1 \cdot 18 \\
1 \cdot 21\end{array}$ & $\begin{array}{l}(1 \cdot 05-1 \cdot 42) \\
(0 \cdot 77-1 \cdot 76) \\
(1.06-1.40)\end{array}$ \\
\hline
\end{tabular}

\section{Results}

MORTALITY

The overall mortality in the cohort did not differ from that expected (420 deaths observed $v 406$ expected, SMR $1 \cdot 04,95 \%$ CI 0.94-1.14; table 2). This was true for deaths from malignant tumours (SMR 1.09) and cardiovascular disease (SMR 1.00). Time since first exposure did not affect these risk estimates.

\section{INCIDENCE OF CANCER}

The overall incidence of cancer was slightly, but significantly, enhanced (233 cases $v 200$ expected, SIR 1.16, 95\% CI 1.02-1.32; table 3 ). When the first 20 years since the start of employment was excluded from the observation period, the SIR increased to $1 \cdot 22$. All five cases of soft tissue sarcoma and all six cases of multiple myeloma had been diagnosed at least 20 years since the start of employment (SIR 4.27, 95\% CI 1.39-9.97; and SIR 2.54, 95\% CI 0.93-5.53 respectively; table 3 ). The risk estimates were above unity and increased slightly with a 20 year induction latency period, also for other diagnoses; breast cancer (SIR 1.47, 95\% CI 0.90-2.33), prostate cancer (SIR 1.31, 95\% CI 0.89-1.90), pancreatic cancer (SIR $1.55,95 \%$ CI 0.67-3.05), lung cancer (SIR $1 \cdot 33$, 95\% CI 0.82-2.11), bladder cancer (SIR $1 \cdot 25,95 \%$ CI $0 \cdot 68-2 \cdot 09$ ),

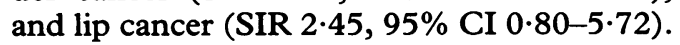

Two cases of sinonasal cancer (one squamous cell carcinoma and one adenocarcinoma) occurred (SIR 3.77, 95\% CI 0.46-13.6), but only one of them had been diagnosed more than 20 years after the start of employment.

With a 20 year induction latency period, the overall incidence of cancer was significantly increased in plant C (SIR $1.40,95 \%$ CI $1 \cdot 08-1 \cdot 81$; table 4$)$. The risk estimates for plant A (SIR 1.16) and plant B (SIR 1.15) were not significantly increased. Three of the cases of soft tissue sarcoma had been employed in plant C (SIR 10.5, 95\% CI $2 \cdot 16-30 \cdot 6$ ), and two in plant B (SIR 2.60, 95\% CI 0.39-9.40). The increased incidence of cancer in plant $\mathrm{C}$ was also partly due to an increased risk for lip cancer (SIR 3.81, 95\% CI 0.79-11.1) and prostate cancer (SIR 1.71, 95\% CI 0.94-2.87). As very few women had been employed in plants $\mathrm{A}$ and $\mathrm{C}$, the risk estimate for breast cancer was almost solely based on plant B (SIR 1.45). The incidence of myelomas was equally distributed between the plants.

Workers employed for at least 10 years had a higher overall incidence of cancer (SIR 1.31, 95\% CI 1.10-1.57) than those employed for a shorter period (SIR 1.09, 95\% CI 0.86-1.37; table 5). There was also a tentative association between duration of employment and risk for prostate cancer, but not for lung cancer. No obvious associations were seen with soft tissue 
sarcoma or myelomas, but the numbers were too few to allow a valid interpretation. Whether the workers had been employed before 1950 or not did not affect the SIRs.

\section{Discussion}

The main result of the study was the significant fourfold increase in risk for soft tissue sarcoma. As all five cases were diagnosed at least 20 years after the start of employment, it is probable that the finding is real. The excess of multiple myelomas was not statistically significant, but still noteworthy.

The occurrence of a healthy worker selection into employment has often been found among industrial workers and may distort the results of a cohort study. This phenomenon is characterised typically by a low overall mortality, and occurs because healthy persons are likely to gain employment. ${ }^{19}$ This effect is said to decrease with time since entry into the cohort. In concordance with our previous observations on workers in other Swedish plants offering unattractive work tasks, ${ }^{20-22}$ no healthy worker selection was found among the leather tanners. We suggest that a major reason for this has been the low Swedish unemployment rates, which has not allowed the management in some industries to be very selective when employing workers.

As nasal cancer is a rare disease, large cohorts are needed to evaluate small or moderate risk excesses. In the present study two cases were observed $v 0.5$ expected, which is not conclusive, but adds some further circumstantial evidence for the hypothesis that there is an increased risk for nasal cancer in the shoe and boot industry. ${ }^{34}$ On the other hand, our study did not add any evidence for an association between leather tanning and lung cancer. A higher proportion of smokers among industrial workers than in the general population, ${ }^{23}$ is a more likely explanation for the slight increase in risk. The present data did not support associations between leather tanning and renal or bladder cancer. A numerical, but not significant, $50 \%$ increase was found for pancreatic cancer, which gives some support for the findings in a Swedish community based case-referent study. ${ }^{8}$

A slight and non-significant excess of prostate cancer was found among leather tanners. No specific environmental agent for prostate cancer has been identified, despite indications of an excess risk for farmers, metal workers, mechanics, repairmen, machine operators, ${ }^{24}$ and workers manufacturing nitrate fertilisers. ${ }^{25}$

Chlorophenols sometimes contain high levels of polychlorinated dibenzodioxins and dibenzofurans (PCDD/Fs), ${ }^{26}$ and consequently blood sampled from two of the tanners in plant A showed increased concentrations of these compounds. ${ }^{27}$ Soft tissue sarcoma is the neoplasm most consistently associated with occupational exposure to PCDD/Fs although some studies do not support this hypothesis. ${ }^{28}$ Moreover, an increased incidence of soft tissue sarcoma has recently been reported in one of the 2,3,7,8-tetrachloro-dibenzo- $p$-dioxin (TCDD) contaminated zones around Seveso. ${ }^{29}$ Chlorophenols have also been used in the Tuscan tanning industry where an excess of soft tissue sarcoma was indicated. ${ }^{14}$ The most plausible explanation for the increased incidence of soft tissue sarcoma in the present study is thus exposure to chlorophenols. Four of the five cases of soft tissue sarcoma had been employed during periods when chlorophenols were used in the plants.

An increased incidence of multiple myeloma in farmers has been ascribed to occupational exposure to herbicides possibly contaminated with PCDD/Fs. ${ }^{30}$ This has gained some support from the finding of an increased incidence of myelomas among women from one of the TCDD contaminated zones around Seveso. ${ }^{29}$ The non-significantly increased incidence of multiple myeloma in the present study may of course be a spurious finding. It is, however, noteworthy that a simultaneous excess of both soft tissue sarcoma and multiple myeloma in a cohort in which exposure to chlorophenols contaminated with PCDD/Fs has occurred. In an ongoing cohort based case-referent study, the impact of exposure to chlorophenols, benzene, halogenated organic solvents, and other carcinogens, will be analysed.

Ms Christina Andersson and Ms Elisabeth Jonsson are gratefully acknowledged for their valuable assistance. The project was supported by grants from the Klippan Leatherworker's fund, the Swedish Work Environment Fund, and the Medical Faculty at the University of Lund.

1 International Agency for Research on Cancer. IARC monographs on the evaluation of the carcinogenic risk of chemicals graphs on the evaluation of the carcinogenic risk of chemicals to humans-wood, leather and

2 Pippard EC, Acheson ED. The mortality of boot and shoe makers, with special reference to cancer. Scand $\mathcal{F}$ Wor Environ Health 1985;11:249-55.

3 Pippard EC, Acheson ED, Winter PD. Mortality of tanners. Br F Ind Med 1985;42:285-7.

4 Comba P, Battista G, Belli S, de Capua B, Merler E, Orsi $\mathrm{D}$, et al. A case-control study of cancer of the nose and Deras a caseMed 1992;22:511-20.

5 Garabrant DH, Wegman DH. Cancer mortality among shoe and leather workers in Massachusetts. Am 7 In Med 1984;5:303-14.

6 Sweeny MH, Walrath J, Waxweiler J. Mortality among retired fur workers. Dyers, dressers (tanners) and service workers. Scand $f$ Work Environ Health 1985;11 257-64.

7 Coggon D, Pannett N, Osmond C, Acheson ED. A survey of cancer and occupation in young and middle aged men. I. Cancers of the respiratory tract. $\mathrm{Br} F$ Ind Med $1986 ; 43: 332-8$

8 Edling $\mathrm{C}$, Kling $\mathrm{H}$, Flodin U, Axelson $\mathrm{O}$. Cancer mortality among leather tanners. $\mathrm{Br}$ f Ind Med 1985;43:494-6.

9 Stern FB, Beaumont J, Halperin WE, Murthy LI, Hills BW, Fajen JM. Mortality of chrome leather tannery BW, Fajen JM. Mortality of chrome leather tannery
workers and chemical exposure in tanneries. Scand $f$ workers and chemical exposure in tant

10 Cole $P$, Hoover $R$, Friedell GH. Occupation and cancer of the lower urinary tract. Cancer 1972;29:1250-60.

11 Vineis P, Magnani C. Occupation and bladder cancer in males: a case-control study. Int $f$ Cancer 1985;35: 599-606.

12 Acheson ED, Pippard EC. Kidney cancer among leathe workers. Lancet 1984;i:563.

13 Cartwright RA, Boyko RW. Kidney cancer among leathe workers. Lancet 1984;i:850-1.

14 Seniori Constatini A, Paci E, Miligi L, Buiatti E, Martelli C, Lenzi S. Cancer mortality among workers in the Tuscan tanning industry. Br $f$ Ind Med 1989;46:384-8.

15 Malker HR, Malker BK, McLaughlin JK, Blot WJ. Kidney cancer among leather workers. Lancet 1984;i:56.

16 Levin SM, Baker DB, Landrigan PJ, Monaghan SV, Frumin E, Braithwaite M, Towne W. Testicular cancer in Frumin E, Braithwaite $M$, Towne W. Testicular cancer in leather tanners

17 Marshall EG, Melius JM, London MA, Nasca PC Burnett WS. Investigation of a testicular cancer cluster 
using a case-control approach. Int $\mathcal{f}$ Epidemiol 1990;19: 269-73.

18 International Agency for Research on Cancer. LARC monographs on the evaluation of the carcinogenic risk of chemicals to humans-overall evaluations of carcinogenicity: an updating of IARC monographs. Vol 1-42, suppl 7. Lyon: IARC, 1987.

19 Checkoway H, Pearce NE, Crawford-Brown DJ. Monographs in epidemiology and biostatistics. Vol 13 (research methods in occupational epidemiology). New York: Oxford University Press, 1989.

20 Hagmar L, Bellander T, Englander V, Ranstam J, Attewell $R$ Skerfving $S$. Mortality and cancer morbidity among $R$, Skers in a chemical factory. Scand $\mathcal{F}$ Work Environ Hoalth 1986;12:545-51.

21 Englander V, Sjöberg A, Hagmar L, Attewell R, Schütz A Möller T, Skerfving S. Mortality and cancer morbidity in workers exposed to sulphur dioxide in a sulphuric acid in workers exposed to sulphur dioxide in a sulphuric ac

22 Hagmar $\mathrm{L}$ kesson $\mathrm{B}$, Nielsen J, Andersson C, Lindén $\mathrm{K}$ Attewell R, Möller T. Mortality and cancer morbidity in workers exposed to low levels of vinyl chloride monomer at a polyvinyl chloride processing plant. $A m \mathcal{F}$ Ind $\mathrm{Med}$ 1990;17:553-65

23 National Central Bureau of Statistics. Smoking in Sweden. Stockholm: National Central Bureau of Statistics, 1965.
24 van der Gulden JWJ, Kolk JJ, Verbeek ALM. Prostate cancer and work environment. F Occup Med 1992;34: 402-9.

25 Hagmar L, Bellander T, Andersson C, Lindén K, Attewell $R$, Möller $T$. Cancer morbidity in nitrate fertilizer workers. Int Arch Occup Environ Health 1991;63:63-7.

26 International Agency for Research on Cancer. LARC monographs on the evaluation of the carcinogenic risk of chemicals to humans-some halogenated hydrocarbons and pesticide exposures. Vol 41, Lyon: IARC, 1986.

27 Rappe C, Nygren M, Buser $H-R$, Kauppinen $T$ Occupational exposure to polychlorinated dioxins and dibenzofurans. In: Hutzinger O, Frei RW, Merian E, Pocchiari $\mathrm{F}$, eds. Chlorinated dioxins and related compounds-impact on the environment. New York: Pergamon Press: 495-513.

28 Axelson 0 Seveso: Disentangling the dioxin enigma? Epidemiology 1993;4:389-92.

29 Bertazzi PA, Pesatori AC, Consonni D, Tironi A, Landi MT, Zochetti C. Cancer incidence in a population accidentally exposed to 2,3,7,8-tetrachlorodibenzopara-dioxin. Epidemiology 1993;4:398-406.

30 Eriksson $\mathbf{M}$, Karlsson $M$. Occupational and other environmental factors and multiple myeloma: a population based case-control study. $\mathrm{Br} \mathcal{F}$ Ind $\mathrm{Med}$ 1992;49: 95-103. 